\title{
Sobre cotas no Brasil
}

\author{
Helga Gahyva
}

KAMEL, Ali. Não somos racistas: uma reação aos que querem nos transformar numa nação bicolor. Rio de Janeiro: Nova Fronteira, 2006.

No âmago da discussão sobre a adoção de um modelo oficial de cotas para "negros" nas universidades públicas brasileiras, o nome de Ali Kamel destaca-se entre os opositores à medida. Seja por meio da imprensa, seja em debates universitários, o jornalista vem, ativamente, corroborando seu repúdio às leis que estabelecem regimes de cota.

Trata-se de diálogo apaixonado. O trabalho de Kamel não oculta seu caráter propositalmente panfletário: livro curto e breve, escrito em linguagem simples, pronto para ser deglutido pelos mais diversos leitores. A escolha do título já aponta as intençôes do autor: ele sabe que, sim, há racismo no Brasil. Com o provocativo título, Kamel pretende tão somente afirmar que a discriminação racial passa ao largo da nossa identidade nacional. $\mathrm{Ou}$ seja, ela existe, mas não é algo definidor daquela entidade abstrata e bem sucedida que se convencionou denominar brasileiro. A verve propagandística, no entanto, em nada reduz o valor do livro, apenas causa algum estranhamento àqueles que, moldados na literatura acadêmica, esperam certa formalidade lá onde ela não precisa existir, isto é, em um livro que compila artigos veiculados na grande imprensa.

Esse foi, provavelmente, o primeiro desafio de Kamel: dar unidade a textos publicados separadamente e, por isso, não raramente repetitivos. No que diz respeito a essa questão, a edição revela-se primorosa; em momento algum, o leitor se pergunta: "Mas ele não disse isso mais acima?". O jornalista não perde o fio da meada e trás para o 
procênio da agenda política um tema que vem sendo tratado de modo não raramente oblíquo, como revela o próprio Kamel: a discussão sobre as medidas de ação afirmativa no Brasil, especialmente a política de cotas para estudantes "negros".

O livro vai além daquilo que o leitor mais fiel já teve oportunidade de constatar nos jornais. Por um lado, unidos, os artigos ganham inédita coerência interna; por outro, a discussão final da obra abandona o terreno estritamente "racial", e volta-se para as políticas de combate à pobreza e distribuição de renda dos dois últimos governos brasileiros.

Mas interessa-nos aqui, especificamente, a visão de Kamel a respeito das políticas de cotas. Para um livro passional, uma resenha assemelhada: concordamos rigorosamente com o autor quando ele aponta os riscos embutidos na contemporânea tentativa de transformar o Brasil em uma nação bicolor. Se passamos ao largo da utopia de uma democracia racial, isto não significa que as práticas racistas, entre nós, não tenham sua especificidade. Em outras palavras, não será copiando o modelo de um país que tem na sua história a marca da segregação - os Estados Unidos da América -, que resolveremos os problemas cotidianamen- te enfrentados pela maioria da nossa população: pobre e de tez escura. Assim, a despeito do valor inconteste do livro de Kamel, gostaríamos de encerrar a presente resenha com um conjunto de quatro críticas.

Em primeiro lugar, o jornalista confunde preconceito e discriminação. $\mathrm{O}$ primeiro é uma categoria psicológica que diz respeito a valores individuais. É ele que existe "aqui e onde mais houver seres humanos" (p. 53), não o racismo. Neste sentido, é preciso ter cuidado para não se embrenhar em luta inútil: não há pessoa no mundo que não tenha algum tipo de preconceito. A guerra é contra a discriminação, seja a que vem daqueles que desprezam outrem em função da cor da pele; seja a que se dirige às classes populares, independentemente dos atributos físicos.

Por outro lado, Kamel talvez dê lugar expressivo às descobertas genéticas na justificação de seu argumento. Essa mesma ciência que hoje advoga a inadequação do conceito de raça, outrora a corroborava. Provavelmente por vício profissional e traumas pretéritos, sociólogos tendem a se manter afastados das discussões próprias às ciências naturais. A genética diz que 
não devemos diferenciar os seres humanos segundo suas supostas características raciais. Ora, não vivemos no "estado de natureza" - não devemos diferenciar as gentes porque somos civilizados, no sentido que dá Elias ao termo.

Em terceiro, Kamel lembranos da dificuldade em definir a cor dos brasileiros - sobremaneira o limite entre negros e pardos -, mas, tal como seus adversários, toma como pouco problemática a categoria "branco". A questão aparece apenas entre parênteses, relegada a segundo plano: "quem é branco no Brasil?” (p. 77). Mesmo acolhendo a visão do autor, pensamos que, por várias vezes, é ele também vítima de certo "mito romântico", construído na primeira metade do século XIX, e até hoje reiterado: a idéia de que somos um país miscigenado.

Sabemos que a matriz teórica do racismo brasileiro teve uma forte marca galófila. Se retrocedermos historicamente até meados do século XVIII francês veremos que as primeiras formulações que tratam de diferenças que se reproduzem geracionalmente entre as gentes opunham, na verdade, "brancos" contra "brancos" - ou aristocratas contra burgueses. Desde a querela das duas raças, na virada do século
XVII para o seguinte, formou-se a idéia de que a França era um país crescentemente miscigenado. Mais além, Arthur de Gobineau, francês a quem erroneamente se aplica o epíteto de "pai do racismo moderno", pouco espaço conferiu às características fenotípicas dos diversos grupos de indivíduos. Sua reflexão encerra o elogio a certa extinta raça ariana, isto é, a um tipo particular de "branco" entre os "brancos". Para o teórico francês, o Brasil era uma nação menos miscigenada do que sua França natal. Aqui, as hierarquias sociais preservavam valores que, na outra face do Atlântico, a Revolução anacronizara.

Por fim, uma provocação: os defensores da adoção da política de cotas em universidades brasileiras julgam prematuro quaisquer diagnósticos, dado seu pouco tempo de funcionamento. Aqueles que a ela se opóem não querem pagar para ver o resultado. A contestação não precisa de "provas". Ela é moral - um imperativo ético de inspiração iluminista: a igualdade entre os homens. Mas, independentemente do lado em que se esteja, o fato é que, desde 1996, com a entrada em vigor da Lei 9.100/95, os partidos políticos são obrigados a destinar às mulheres $20 \%$ das candidaturas aos 
postos no Legislativo. O impacto desta lei foi nulo. Mas já há, entre nós, uma lei de âmbito nacional que, como no caso das cotas raciais, estabelece uma diferença entre iguais - ainda que de sexo diferentes. Duas distinções são, entretanto, significativas: em primeiro lugar, as discussões em torno da formulação e implementação da lei de 1995 não tiveram dificuldades em definir o seu alvo. Ninguém se perguntou, afinal, quem seria mulher no Brasil. Em segundo, suas conseqüências são bem menos desastrosas: as cotas raciais podem produzir uma nação bicolor; as cotas feministas têm que se contentar com os anedóticos casos narrados Brasil afora de candidatas que apenas "preenchem” as exigências legais - a não ser que nos transformemos em uma nova Tróia. Uma Tróia bicolor? 